九州大学学術情報リポジトリ

Kyushu University Institutional Repository

Weiningia from Millerella yowarensis Zone of the Akiyoshi Limestone Group : Carboniferous brachiopods from Akiyoshi, Southwest Japan, Part VI

Yanagida, Juichi

faculty of Science, Kyushu University

Matsusue, Kazuyuki

Energy Division, OYO Corporation

https://doi.org/10.5109/1543666

出版情報: 九州大学大学院理学研究院紀要 : Series D, Earth and planetary sciences. 29 (1)， pp. 87-100, 1995-12-26. Faculty of Science, Kyushu University

バージョン：

権利関係 : 
Mem. Fac. Sci. Kyushu Univ., Ser. D, Earth Planet. Sci., Vol. XXIX, No.1, pp.87-100, text-figs. 1-5, table 1, plates 5-6, December 25, 1995.

\title{
Weiningia from the Millerella yowarensis Zone of the Akiyoshi Limestone Group \\ ( Carboniferous brachiopods from Akiyoshi, Southwest Japan, Part VI )
}

\author{
Juich YANAGIDA and Kazuyuki MATSUSUE*
}

\begin{abstract}
Two new species of Weiningia, W. sugimurai and W. haikawai, are described from the Upper Serpukhovian Millerella yowarensis Zone of the Akiyoshi limestone Group. Weiningia is a martinid genus originally found from South China. Outside Japan and China it is only known from southern Ural and Fergana. At present the genus Weiningia is restricted in Asian regions in its geographical distribution and from the Lower Serpukhovian (E1) to Middle Bashkirian (G1) in its stratigraphical occurrence. Therefore Weiningia is rather unfamiliar even to Palezoic brachiopod specialists. Turning to the Weiningia species in the Akiyoshi limestone Group, we realize extraordinarily abundant occurrence of them in the lower part of the Millerella yowarensis Zone. In the Akiyoshi limestone Group Weiningia reveals as an indicator of upper Serpukhovian in association with fusuline Millerella yowarensis. The densely crowded occurrence of Weiningia and the shell morphology give us some suggestions for its living habits and habitats.
\end{abstract}

\section{Introduction}

The authors introduced two new species of Weiningia in 1990 from the lower part of the Millerella yowarensis Zone, upper Lower Carboniferous Serpukhovian, in the Akiyoshi limestone Group. The Millerella yowarensis Zone is characterized by conspicuous development of an organic reef complex in the Akiyoshi limestone Group. The development was accelerated by the abundant appearance of chaetetids, a new element of the reef builders (NAGAI, 1979). The newly described brachiopods, Weiningia sugimurai, n.sp., and W. haikawai, n.sp., always occur in crowds in several localities on the Akiyoshi limestone plateau. This common character to all localities is fairly remarkable. Their habitats are suggested to be slightly backward to the reef front. Both new species of Weiningia are known from the lower part of the Millerella yowarensis Zone, namely from the Okubo, Ryugoho, Yowara (Uzura Quarry), Sumitomo-Osaka Cement Quarry, Ohira-yama, and Shishidedai areas. In general Weiningia sugimurai shows the transverse form and $W$. haikawai has round to slightly elongated form. They occur from whole localities, however, the former shells predominate in the Uzura Quarry, the large quarry of Sumitomo-Osaka Cement Co. near the Uzura Quarry and the Ryugoho

Manuscript received October 6, 1995; accepted October 27, 1995

* Energy Division, OYO Corporation, Tokyo. 


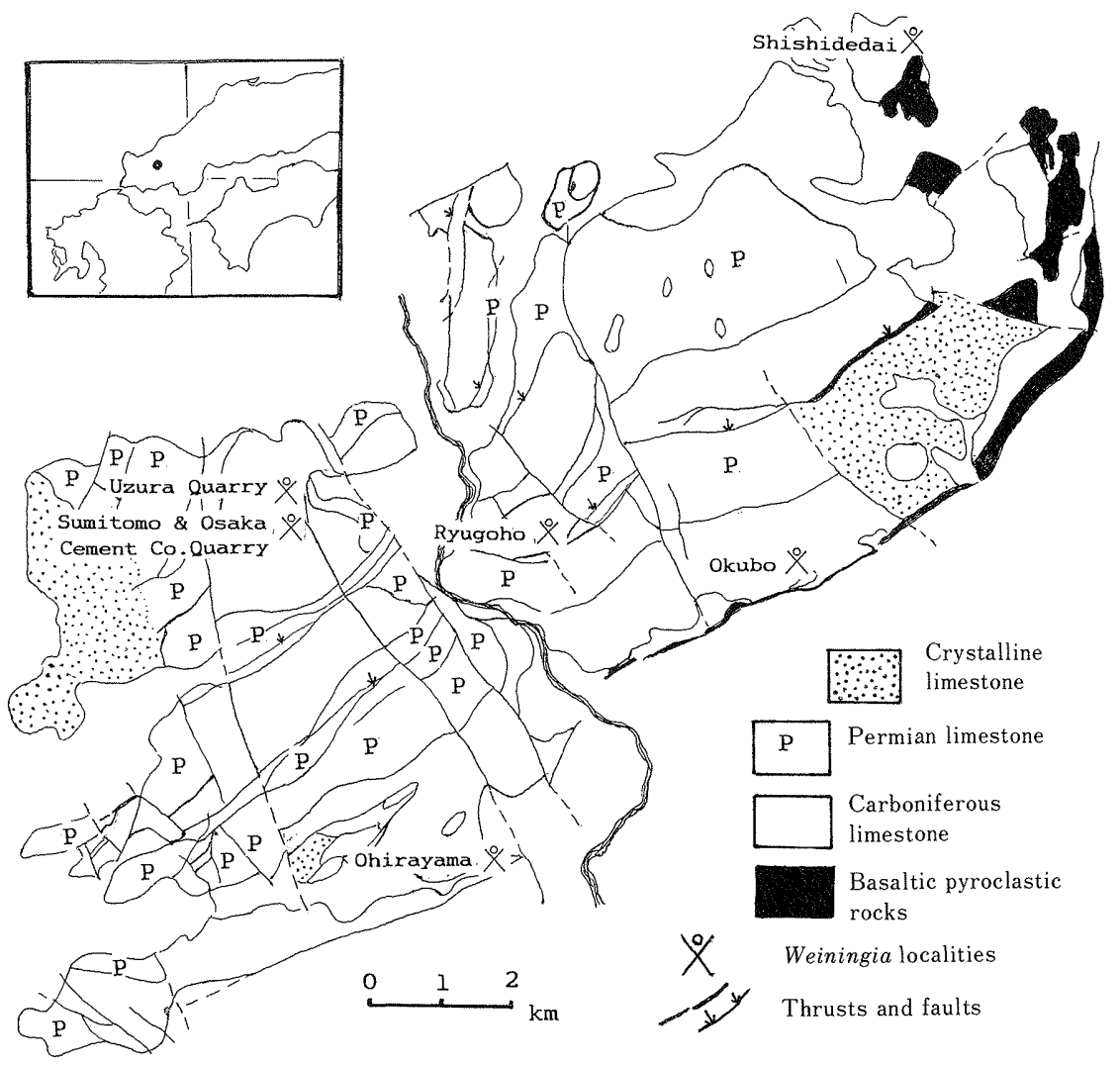

Fig. 1. Geological map showing distribution of the Permian and Carboniferous limestones of the Akiyoshi limestone Group and the fossil localities of Weiningia (map simplified after OTA, 1977).

area. On the other hand, W. haikawai is the most abundant in occurrence in southern to southeastern part of the limestone plateau, namely in the Okubo, Ohira-yama and Shishidedai areas. On the whole it is considered that the original habitat of Weiningia was an environment where the current of water was remarkable. Because the shell bearing limisetones are composed of sandy to silty sediments and very well sorted bioclasts. It is very common to observe patch reefs which sporadically distribute in this environment. Weiningia sugimurai seems to be originally lived in a habitat where the current of water was relatively stronger than that of $W$. haikawai. In this paper, we amend the identification of two species of Cleiothyridina expansa and C. royssii from the Uzura Quarry (YANAGIDA, 1962). They were misidentified by the senior author who considered that both species probably have the hinge plate, though it was not confirmed by serial sections at that time. Now the former species is revised to Weiningia sugimurai, n.sp., and the latter one is emended to belong to W. haikawai, n.sp. Their taxonomic positions are revised and they are redescribed with some new characters on the external and internal morphology.

Acknowledgments: We wish to express our sincere appreciation to Messrs. Akihiro SugIMURA and Takehiko HAIKAWA of the Akiyoshi-dai Science Museum 
for their kind cooperation in our field work for long years as colleagues of our reserch group of the Akiyoshi Limestone. Special thanks are due to Dr. Masamichi OTA, the Direcor of the Kitakyushu Museum of Natural History, for his valuable discussions and kind cooperation, and help in giving us facilities for our field works. Financial support for the present study was provided by the Ministry of Education, Science and Culture, Japanese Government.

\section{Systematic description}

Order Spiriferida WAAGEN, 1883

Suborder Spiriferidina WAAGEN, 1883

Superfamily Martinioidea WAAGEN, 1883

Family Martinidae WAAGEN, 1883

Subfamily Martininae WAAGEN, 1883

Genus Weiningia CHIANG and LiAO, 1974 ( = Elenchus AlEKsandrov, 1973)

Type species.-Weiningia transversa CHING and LIAO, 1974

Remarks.-ALEXANDROV(1973) proposed Elenchus with E. areatus as the type species from the Lower Serpukhovian of southern Ural. The diagnostic characters of Elenchus and Weiningia is nearly same, excepting for the dorsal interarea. Elenchus apparently has the dorsal interarea and in Weiningia interarea is restricted in the pedicle valve. The senior author once had an occasion of examining the holotype and other specimens of the type species of Weiningia in Nanjing Institute of Geology and Paleontology and he noticed that the brachial valve sometimes has interarea. He recognized that Elenchus and

\begin{tabular}{|c|c|c|c|c|c|c|c|c|c|}
\hline \multicolumn{2}{|l|}{ AKIYOSHI } & \multicolumn{3}{|c|}{ SOUTH CHINA } & \multirow{2}{*}{\multicolumn{4}{|c|}{$\begin{array}{l}\text { SOUTHERN URAL } \\
\text { AISENVERG et al. } 1979\end{array}$}} & W. EUROPE \\
\hline Matsusue 19 & & \multicolumn{3}{|c|}{$\begin{array}{l}\text { WANG et al. } 1987 \\
\quad \& \text { RUI } 1987\end{array}$} & & & & & $\begin{array}{c}\text { CEPHALOPOD } \\
\text { ZONE }\end{array}$ \\
\hline $\begin{array}{l}\text { Profusulinella } \\
\text { beppensis Zone }\end{array}$ & \multirow{7}{*}{ 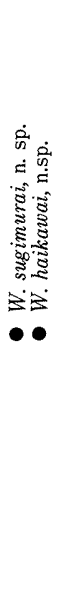 } & \multirow{4}{*}{ 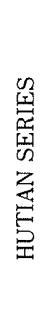 } & \multirow{2}{*}{$\begin{array}{c}\text { WEININGIAN } \\
\text { STAGE }\end{array}$} & \multirow{4}{*}{$\bullet \bullet \bullet \bullet$} & \multirow{3}{*}{\multicolumn{3}{|c|}{ BASHKIRIAN STAGE }} & \multirow{7}{*}{ 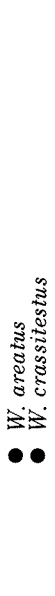 } & $G_{2}$ \\
\hline $\begin{array}{l}\text { Pseudostaffella } \\
\text { antiqua Zone }\end{array}$ & & & & & & & & & $\mathrm{G}_{1}$ \\
\hline $\begin{array}{l}\text { Pseudostaffella } \\
\text { minuta Zone }\end{array}$ & & & \multirow{2}{*}{$\begin{array}{l}\text { LUOSUAN } \\
\text { STAGE }\end{array}$} & & & & & & R \\
\hline $\begin{array}{c}\text { Millerella } \\
\text { yowarensis Zone }\end{array}$ & & & & & 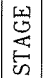 & UPPER & $\begin{array}{c}\text { Bogdanovsky } \\
\text { Horizon }\end{array}$ & & $\mathrm{H}$ \\
\hline \multirow{2}{*}{$\begin{array}{c}\text { Eostaffela } \\
\text { ikensis Zone }\end{array}$} & & \multirow{3}{*}{ 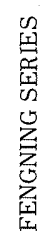 } & \multirow{3}{*}{$\begin{array}{c}\text { DATANGIAN } \\
\text { STAGE }\end{array}$} & \multirow{3}{*}{ 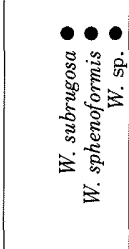 } & \multirow{2}{*}{ 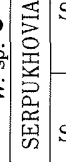 } & SUBSTAGE & $\begin{array}{c}\text { Ustsarbaisky } \\
\text { Horizon }\end{array}$ & & $\mathrm{E}_{2}$ \\
\hline & & & & & & $\begin{array}{l}\text { LOWER } \\
\text { SUBSTAGE }\end{array}$ & $\begin{array}{l}\text { Nizhnegubakh- } \\
\text { insky Horizon }\end{array}$ & & $E_{1}$ \\
\hline $\begin{array}{c}\text { Eostaffella } \\
\text { mosquensis Zone }\end{array}$ & & & & & \multicolumn{3}{|c|}{ VISEAN STAGE } & & \\
\hline
\end{tabular}

Table 1. Correlation chart of the Mid-Carboniferous among four regions with occurrence of Weiningia. 
Weiningia are one and the same genus. However, it became clear that the name Elenchus was preocupied by SWAINSON (1840) for a trochacean archaeogastropod. Therefore the generic name Weiningia is valid for the present species. According to CHING and LIAO (1974), the diagnostic character of Weiningia is as follows: the transversely rounded or elongately oval outline, biconvex shell, high interarea of pedicle valve, open delthyrium, narrow and shallow median sulcus, less convex brachial valve than the opposite valve, conspicuous growth lines on both valves, internally strong teeth in pedicle valve, extremely large and flabellated muscle scars, large cardinal process and laterally extended spiralia in brachial valve.

The familial position of Weiningia was proposed by CARTER et al. (1994).

\section{Weiningia sugimurai YANAGIDA and MATSUSUE, n. sp. Pl. 1, Fig. 1}

1962. Cleiothyridina expansa, YANAGIDA. Mem. Fac. Sci., Kyushu Univ., Ser. D, vol. 12, no. 1, pp. 99-103, pl. 16, figs. 1-9, pl. 17, fig. 1.

Material. - Holotype, GK-D 31811. Paratype, GK-D 30027 (YANAGIDA, 1962, pl. 16, fig. 1). Internal structures were examined by the serial sections of a specimen (GK-D 31812) from Okubo (refer to MF 173 of MATSUsue, 1986).

Description.-The shell is subequally biconvex and transversely elliptical in outline with the largest width at anterior to the hinge line. The pedicle valve is with shallow and narrow median sulcus, becoming very weak posteriorly. The beak is small and slightly incurved over delthyrium. The interarea is low but distinct. The brachial valve is weakly convex without fold. The median longitudinal part of the brachial valve is flattened with suggestion of the faint depression. Both valves are ornamented by tightly arranged growth lamellae, about 15 to 20 in space of $1 \mathrm{~cm}$ on the anterior surface. They are usually strong anteriorly and often show the imbricated structure. The faint radial striae are present, about 20 in the space of $1 \mathrm{~cm}$, crossing the lamellae.

The pedicle valve interior is strongly thickened by the secondary shells in the umbonal region. The hinge teeth are strong. The dental plates are thick but nearly absent. The brachial valve interior is with a remarkably large and ventrally projected cardinal process and large sockets. In general both valves are

\section{Explanation of Plate 5}

All specimens are in x 1.2 and from a locality MF 173 in the Okubo area.

Fig. 1. Weiningia sugimurai YANAGIDA and MATSUSUE, n. sp. $\cdots \ldots \ldots \ldots \ldots \ldots \ldots$ page 90 la-c. Dorsal, lateral and ventral views of a complete specimen, holotype, GK-D 31811 .

Fig. 2-5 Weiningia haikawai YANAGIDA and MATSUSUE, n. sp. $\cdots \ldots \ldots \ldots \ldots \ldots$......... page 95 2a-c. Dorsal, lateral and ventral views of a paratype, GK-D 31813. 3a-d. Ventral, posterior, lateral and dorsal views of a paratype, GK-D 31814. 4a-d. Lateral, anterior, ventral and dorsal views, GK-D 31815. 5. Longitudinal section, GK-D 31816, showing incomplete distribution of spiralia. 
Mem. Fac. Sci., Kyushu Univ., Ser. D, Vol. XXIX

Plate 5
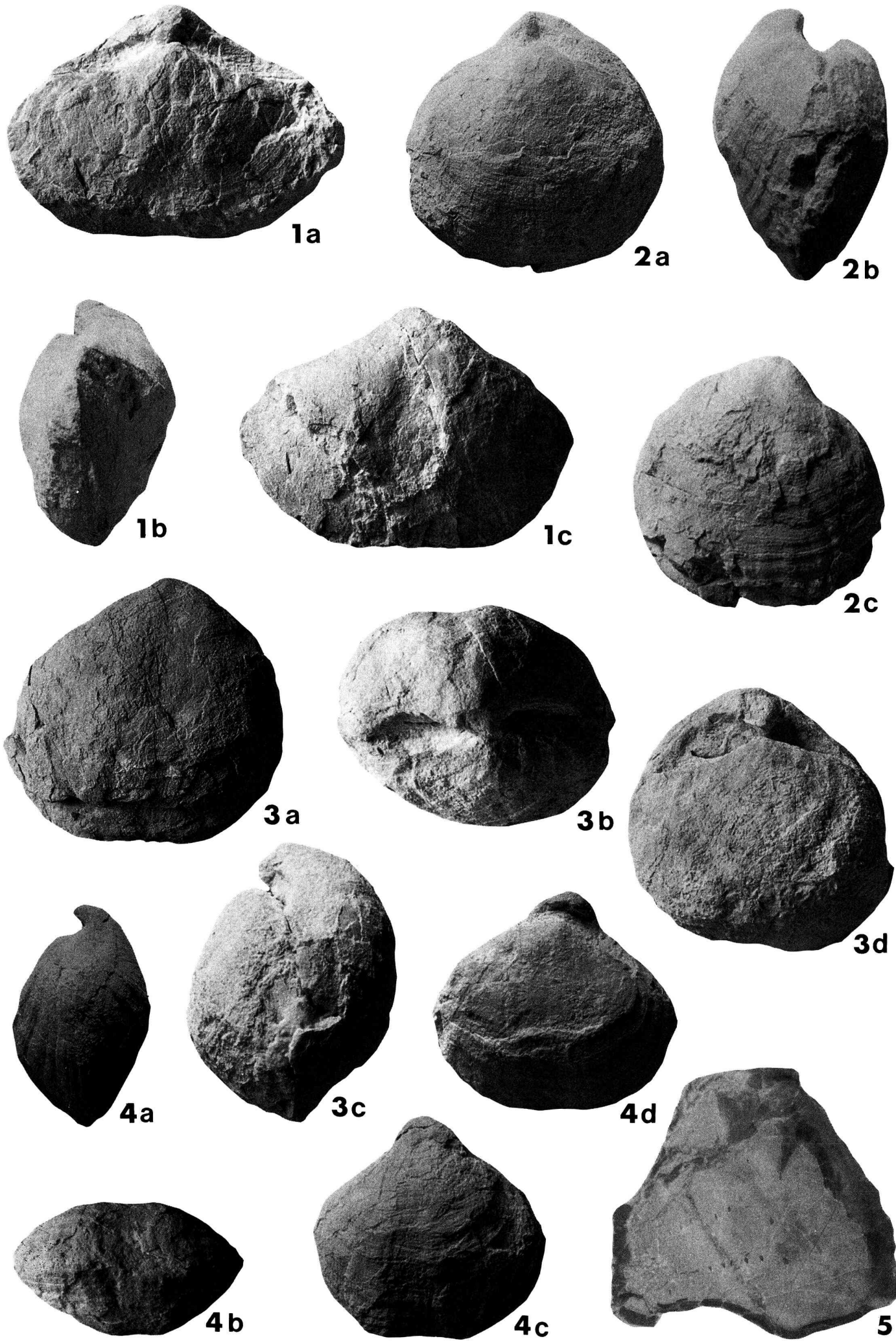

J. YANAGIDA and K. MATSUSUE : Weiningia from the Akiyoshi Limestone Group 


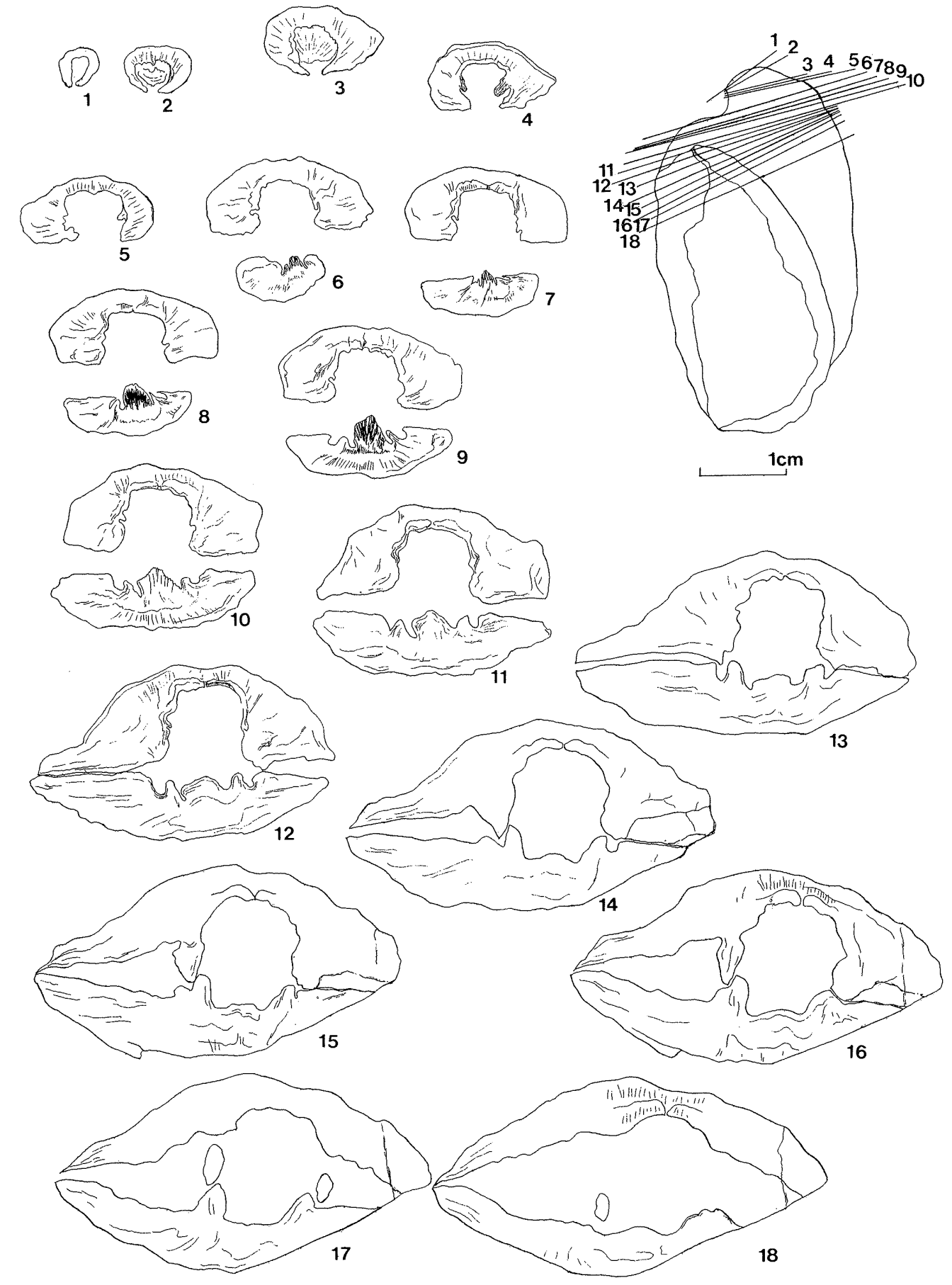

Fig. 2. Transverse serial sections of Weiningia sugimurai YANAGIDA and MATSUSUE, n.sp., GK-D 31812. 
extraordinarily thick, especially in the posterior region of adult shells. The specimens show a great variation in external characters, namely in ornamentation, thickness and outline. They are grouped into two forms, a transversely elongate form and a suborbicular one, though a gradual change between them can be realized. As far as the median sulcus and/or fold are concerned they are constantly very weak in both groups. A shell ornamented by smooth surface or weak growth lines is thinner than that having imbricated growth lamellae.

Measurements in $\mathrm{mm}$ :

$$
\begin{array}{cc}
1 \text { (holotype) } & 2 \text { (paratype) } \\
\text { GK-D } 31811 & \text { GK-D } 30027
\end{array}
$$

length

pedicle valve $\quad 31.0$

brachial valve $\quad 25.0$

width

thickness

20.0

17.0

Etymology. - This species is dedicated to Mr. Akihiro SugIMURA, who kindly cooperated for long years as a colleague of our Akiyoshi Limestone research group.

Remarks.-In general the young shells of W. sugimurai, n. sp., have relatively thin valves comparing to the size of shell. Cross sections of shells indicate that the accretion of the secondary shells rapidly accelerate in the mature stage of growth.

Weiningia transversa CHING and LIAO from the basal part of the Upper Carboniferous Weining Formation of Guizhou, South China, is distinguishable from the present species by having the more rounded outline, much larger size of adult shell, higher interarea, more prominent beak and stronger concentric rugae in distance on both valves. W. elongata was reported by YANG (1985) but the original description is not accessible. According to YANG, W. elongata is accompanied by $W$. transversa in western Guizhou. W. sphenaeformis (GRABAU, 1936) from Guizhou is distinct from $W$. sugimurai by its less transverse outline and smaller size. CHING and LIAO (1984) showed the faunal assemblage zones in South China including W. sphenaeformis. LI (1987) described W. subrugosa from the Loucheng Formation of South China. W. subrugosa, however, has laterally tapering more transverse outline and the smaller size comparing with the present species.

W. crassitestus, originally described by YANISHEVSKY(1918) under the name of Spirifer is clearly distinguishable from $W$. sugimurai by its more rounded outline. W. areatus described by ALEXANDROV(1973) by the name of Elenchus from the Serpukhovian Nizhenegubekhinsky horizon differs from the present species by having the longitudinally elongate form with high interarea.

Occurrence.-This species is especially abundant in occurrence in the western part of the distributed areas. 
Mem. Fac. Sci., Kyushu Univ., Ser. D, Vol. XXIX

Plate 6
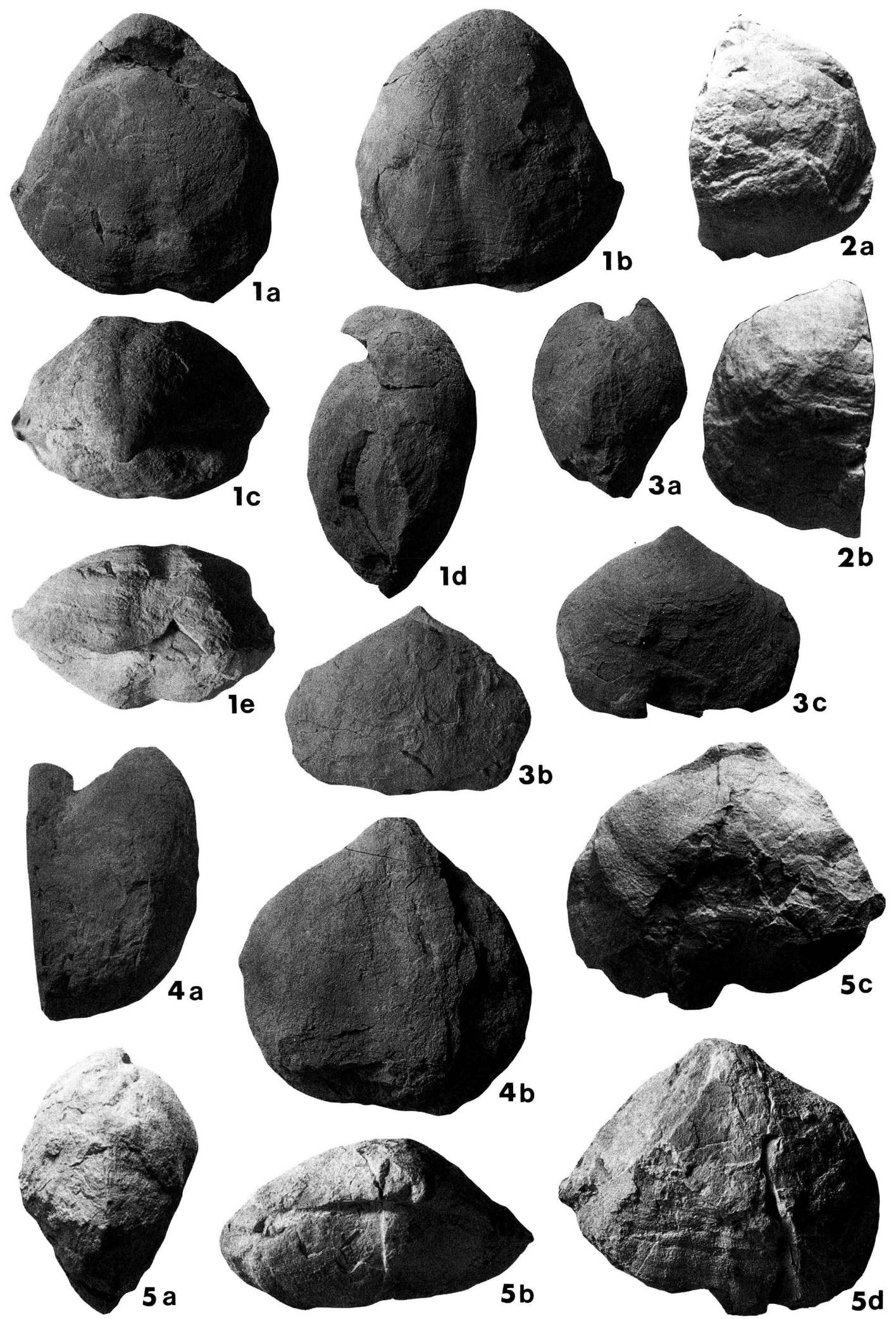

J. YANAGIDA and K. MATSUSUE : Weiningia from the Akiyoshi Limestone Group 
Weiningia haikawai YANAGIDA and MATSUSUE, n. sp.

Pl. 1, Figs. 2-5; Pl. 2, Figs. 1-5.

1962. Cleiothyridina royssii, YANAGIDA. Mem. Fac. Sci., Kyushu Univ., Ser. D, vol. 12 , no. 1 , pp. 103-110, pl. 17, figs. 2-11.

Material.-Holotype, GK-D 31817. Paratypes, GK-D 31813 and GK-D 31814. Internal structures were examined by the serial sections of two specimens from Okubo, GK-D 31818 and GK-D 31822, respectively.

Description.-The shell is subround to elongately oval in outline and subequally or slightly ventri-biconvex. The shell outline almost always shows asymmetrical form. The hinge line is much shorter than the largest width which locates nearly at the midlength. The pedicle valve is strongly convex with a beak much incurved over the delthyrium. The delthyrium is open and the interarea is low, slightly concave and variably developed. The median sulcus is narrow and shallow, originating near the beak and anteriorly extends in irregular trace, corresponding to the asymmetrical form of shell. The brachial valve is moderately convex, usually slightly less convex than the pedicle valve, but rarely some specimens show nearly same or more convex brachial valve than the opposite valve. Very low interarea is rarely observed in the brachial valve. The median longitudinal depression is variably developed in some specimens (pl. 1, fig. 4; pl. 2, fig 1). The surface ornamentation is fundamentally same with that of $W$. sugimurai. But in some specimens radial and broadly low, fine ornaments are visible.

Measurements in mm.

$\begin{array}{lll}1 \text { (holotype) } & 2 \text { (paratype) } & 3 \text { (paratype) } \\ \text { GK-D31817 } & \text { GK-D31813 } & \text { GK-D31814 }\end{array}$

$\begin{array}{llll}\text { length } & & & \\ \quad \text { pedicle valve } & 37.5 & 35.0 & 35.0 \\ \quad \text { brachial valve } & 31.0 & 31.0 & 31.0 \\ \text { width } & 37.0 & 34.0 & 34.0 \\ \text { thickness } & 24.2 & 24.0 & 27.5\end{array}$

Internally both valves are extraordinarily thick and the internal increment of secondary layer in the mature stage of growth is conspicuous as it is observed in W. sugimurai. The pedicle valve is umbonally much thickened by the secondary deposits. The hinge teeth are remarkably strong. The dental plates are absent.

\section{Explanation of Plate 6}

All specimens are in x 1.2 and from a locality MF 173 in the Okubo area.

Fig. 1-5 Weiningia haikawai YANAGIDA and MATSUSUE, n. sp. page 95 1a-e. Dorsal, ventral, posterior, lateral and anterior views, holotype, GK-D 31817. 2a, b. Dorsal and ventral views of an incomplete specimen, GK-D 31818. 3a-c. Lateral, dorsal and ventral views of a complete specimen, GK-D 31819. $4 \mathrm{a}$, b. Lateral and ventral views of a complete specimen, GK-D 31820. 5a-d. Lateral, posterior, dorsal and ventral views of a large specimen, GK-D 31821 . 
The brachial valve interior is with deep sockets and very strong crural plates. The cardinal process is very strong and ventrally projected, anteriorly continuous to a low and strong median septum. The fragmentary spiralia are observable. The longitudinal serial sections show the very thick muscle platform and strong crural plates.

Etymology.- This species is dedicated to Mr. Takehiko HAIKAWA, who kindly cooperated for long years as a colleague of our research group of the Akiyoshi Limestone.

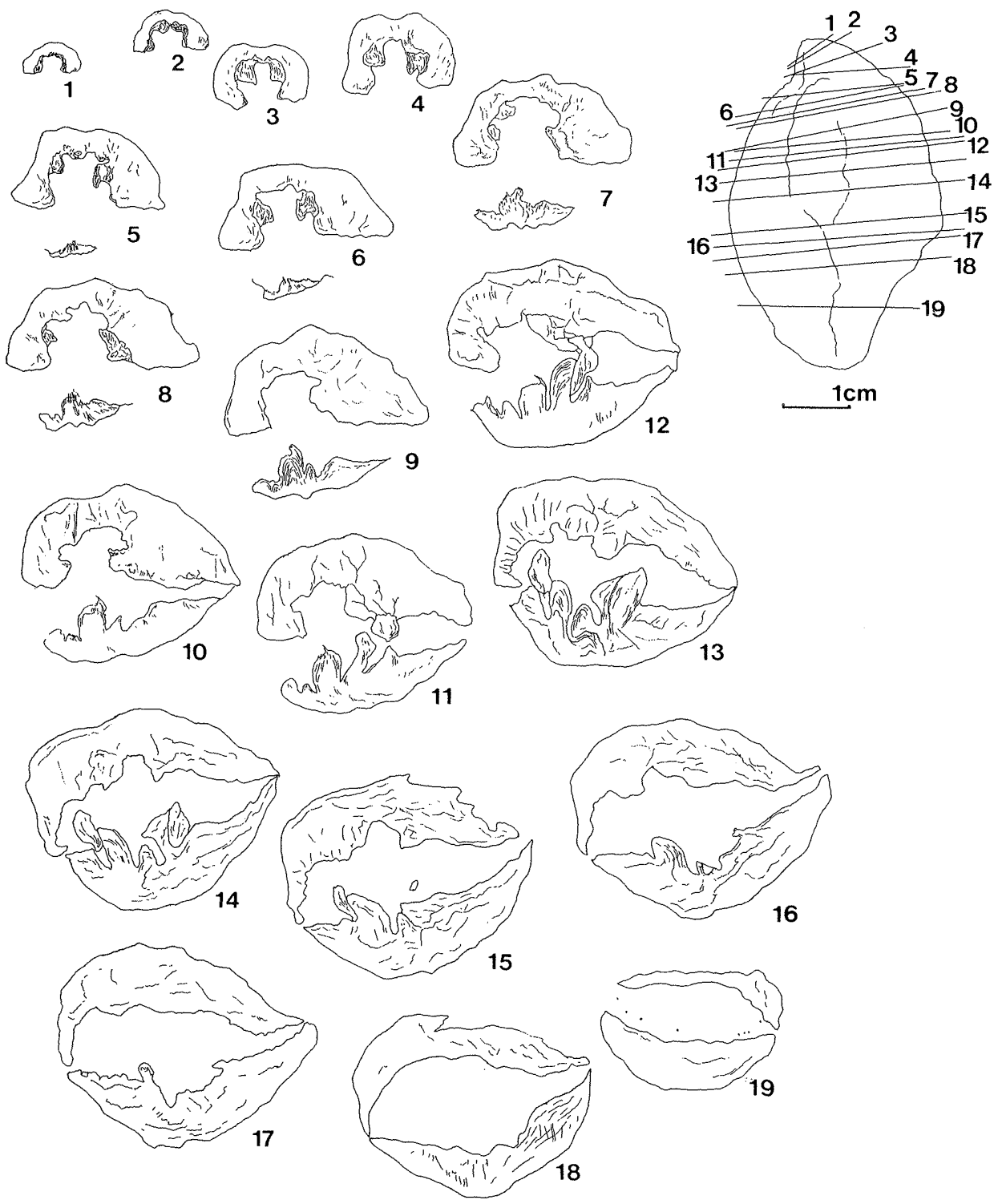

Fig. 3. Transverse serial sections of Weiningia haikawai YANAGIDA and MATSUSUE, n. sp., GK-D 31822, showing thick valves, strong cardinal process, teeth, deep sockets and a fragmentary section of spiralia (19). 
Remarks.-W. haikawai is characterized by the strongly convex shell with rounded outline. It often has the median longitudinal, shallow depression on the brachial valve, corresponding to sulcus of the pedicle valve. This character is clearer than that in W. sugimurai. Moreover almost all of shells are more or less twisted. This character is well recognizable by trace of the median sulcus.

Among the known species of Weiningia the present species is closely related
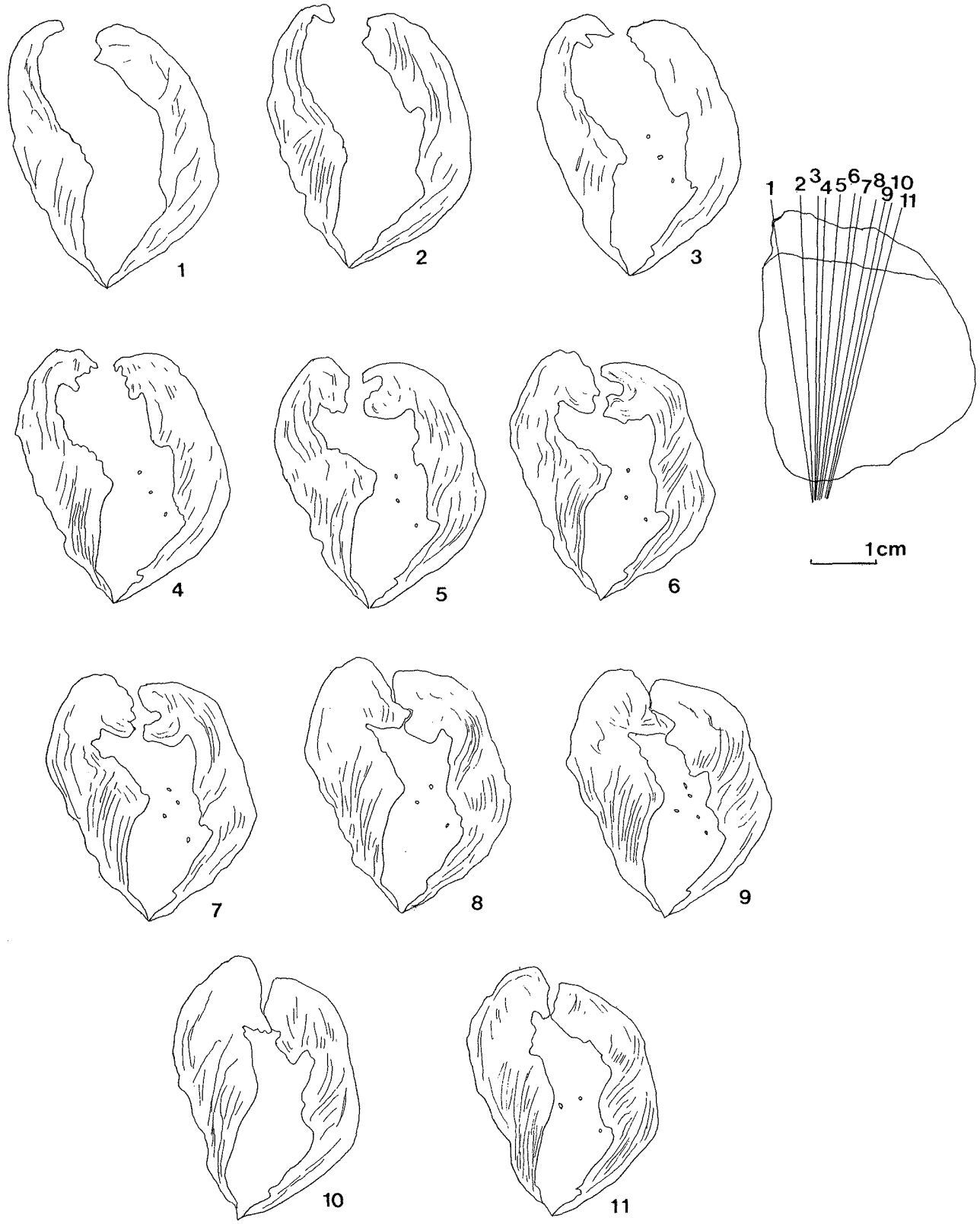

Fig. 4. Longitudinal serial sections of Weiningia haikawai YANAGIDA and MATSUSUE, n. sp., GK-D 31818, showing very thick shell, strong articulation, elevated muscle field with fragmentary remains of spiralium. 
to $W$. crassitesta (YANISHEvSKY) from the Lower Serpukhovian of Fergana (YANISHEVSKY, 1918) and southern Ural (AlEXANDROV, 1973). W. haikawai, however, has the more strongly convex valve, and more elongately oval outline than W. crassitesta.

Asymmetrical form of Weiningia shell was also noticed by YANISHEVSKY(1918) and ALEXANDROV(1973). And the existence of the median longitudinal depression in the brachial valve of $W$. crassitesta was also remarked by ALEXANDROV on specimens from Fergana and southern Ural. W. areata (ALEXANDROV) from southern Ural is distinct from $W$. haikawai by its less convex valves, more longitudinally elongate beak region, and broadly open delthyrium.

Occurrence.-This species is known from the whole localities, however, it is very abundant in occurrence in the Okubo and Shishidedai areas.
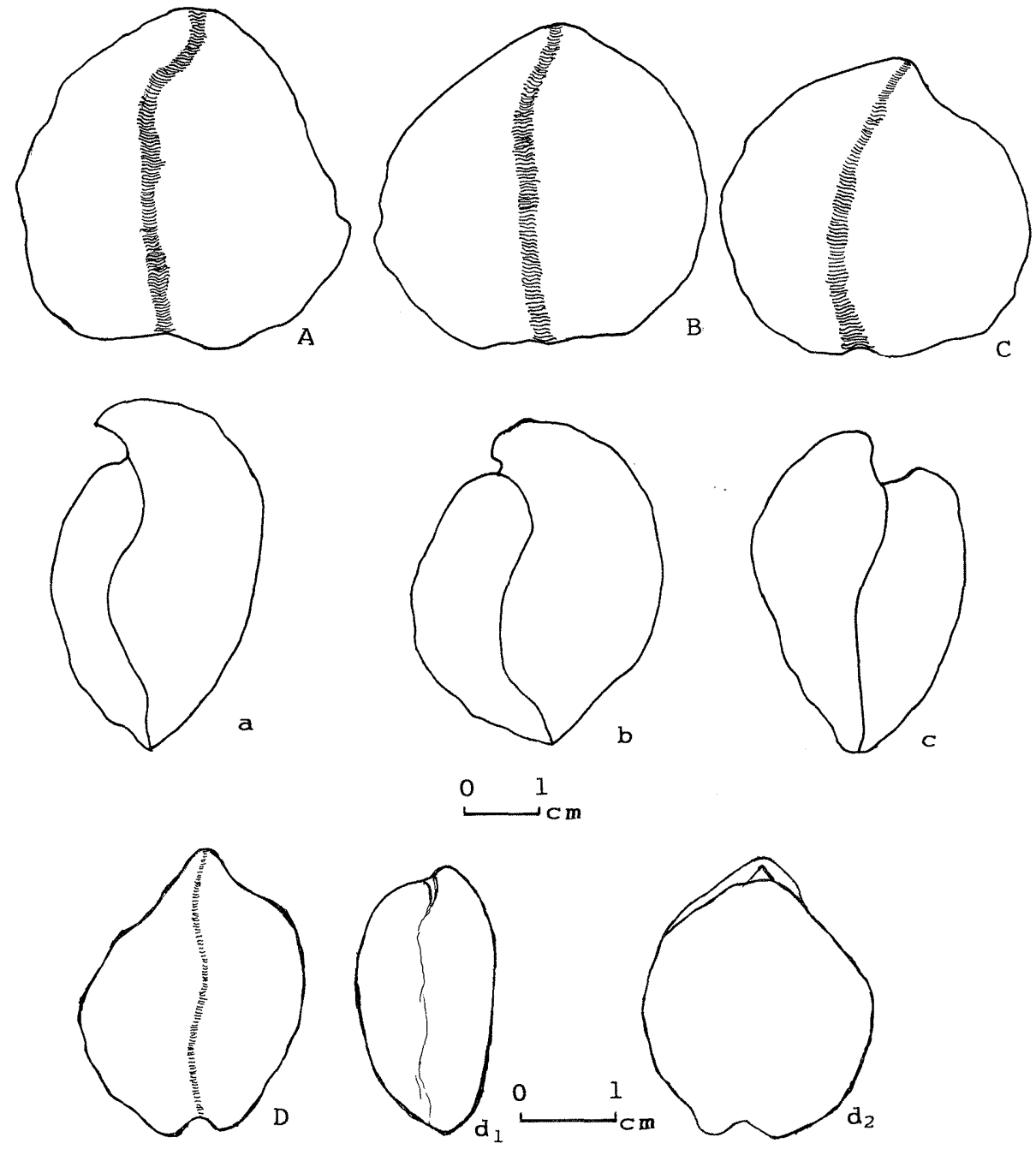

Fig. 5. Deformation of valves discriminated by the trace of sulcus of pedicle valve. Aa-Cc. Weiningia haikawai, GK-D 31817, 31814 and 31813, respectively. D, $\mathrm{d}_{1}, \mathrm{~d}_{2}$. Weiningia areatus, an enlarged figure after ALEXANDROV (1973). 


\section{Paleoecological consideration}

W. sugimurai and W. haikawai occur from 6 localities in the Millerella yowarensis Zone. The Weiningia shells always occur in crowds. The valves are commonly articulated. But well worn shells also occur in random distribution. Matrices are filled by well sorted fragments of crinoids and foraminifers. In the Okubo area well rounded bioclasts and intraclasts are discernible. Therefore it is recognizable that they are largely affected by waves and currents. The articulated shell beds are characterized by having the fine bioclasts and foraminifers in the inside of the articulated shell and/or the gap between shells. Algal biolithites are also common near the articulated shell beds. In general waves and/or currents in the Okubo area were not so effective. However, in the Shishidedai area, for instance, disarticulated shells densely piled up and the fine bioclasts and lime muds fill up the gaps. This occurrence is also partly recognizable in the Okubo and Ryugoho areas. Therefore these disarticulated shell beds are supposed to be formed by throwing of the strong waves along beaches. It is presumable that the Weiningia shells were deposited in an environment of the reef edge and/or slightly backward reef flat. The original habitats of Weiningia are considered to be on biolithites of the reef flat or on the fine sands between biolithites. Weiningia shells also support the above consideration. They seem to be originally fond of crowded lives under the better circulation of waters. The extraordinarily thick shells, large openings of delthyrium, and often twisted shells are all well in harmony with litho-and biofacies of these paleoenvironments.

\section{References}

Aisenverg, D. E. , Brazhnikova, N. E. , Vassilyuk, N. P. , Vdovenko, M. V. , Gorak, S. V. , Dunaeva, N. N. , Zernetskaya, N. V. , Poletaev, V. I. , Potievskaya, P. D. , Rotai, A. P. and S ERgeva, M. T. (1979): The Carboniferous sequence of the Donetz basin: A standard section for the Carboniferous System. 197-224. In WAGNER, R. H. , HigGins, A. C. and MEYen, S. V. (eds.), The Carboniferous of the USSR. Yorkshire Geol. Soc. Occ. Publ., (4).

Carter, J. L. , Johnson, J. G. , Gourvennec, R. and Hon, H. (1994): A revised classification of the Spiriferid brachiopods. Ann. Carnegie Mus., 63 (4), 327374.

ChING, Y. and Liao, Z. (1974): Carboniferous brachiopoda. 275-283, pls. 142-147. In Nanjing Inst. Geol. Paleont. (ed.), Handbook of stratigraphy and Paleontology of Southwest China. Science Press. Beijing (in Chinese).

— and (1984): Carboniferous brachiopod faunas of China. 245-250. In Dutro, Jr., J.T. and Pfefferkorn, H.W. (eds.), Neuv. Congr. Int. Strat. Geol. Carbon., Washington and Champaign-Urbana 1979, C.R.5, Southern Illinois Univ. Press.

Grabau, A. W. (1936): Early Permian fossils of China Pt II. Fauna of the Maping Limestone of Kwangsi and Kweichow. Palaeont. Sinica, [B], 8 (4), 1-320, pls. $1-31$.

LI, S. (1987): Late Early Carboniferous to early Late Carboniferous brachiopods 
from Qixu, Nandau, Guangxi and their paleoecological significance. 132-150, pl. 1. In WANG, C. (ed.), Carboniferous boundaries in China. Science Press, Beijing.

NAGAI, K. (1979): Organic reef deposits developed in the lower part of the Akiyoshi limestone Group. Chikyu, 1(9), 661-667(in Japanese).

OTA, M. (1977): Geological studies of Akiyoshi, Part 1. General geology of the Akiyoshi limestone Group. Bull. Akiyoshi-dai Mus. Nat. Hist., (12), 1-33, pls. 1-3.

RUI, L. (1987): Fusulinaceans across Mid-Carboniferous boundary at Luosu of Luodian County, Southern Guizhou. Acta Palaeont. Sinica, 26(4), 367-391 (in Chinese with English abstract).

Solomina, R.V. and Alexandrov, V. A. (1973): Brachiopoda. 86-131, pls. 21-34. In Einor, O.L. (ed.), The stratigraphy and fauna of the Carboniferous deposits from the River Shartym (Southern Urals). Vishcha Shkola (in Russian).

SWAINSON, W. (1840): A treatise on malacology; or the natural classification of shells and shell fish.-VIII+1-419. (inaccessible).

WAagen W.H. (1883): Salt Range fossils. Productus Limestone fossils IV, Brachiopoda. Palaeontologia Indica, [13], 1, 391-546, pls. 29-49.

WANG Z., RUI, L. and ZHANG, L. (1987): Conodont and fusulinid sequence of the Upper Carboniferous-Early Permian of Nashui, Luodian, South China. Jour. Stratigraphy, 11(2), 155-159 (in Chinese).

YANAGIDA, J. (1962): Carboniferous brachiopods from Akiyoshi, Southwest Japan Part 1, Mem. Fac. Sci., Kyushu Univ. [D], Geology, 12(1), 87-127, pls. 14-21.

- and MATSUSUe, K. (1991): Biostratigraphic and paleoecological significance of Carboniferous Weiningia from Southwest Japan. 333-340. In MACKINNON, D. I., LEE, D. E. and CAMPBELL, J. D. (eds.), Brachiopods through time. Balkema, Rotterdam.

YANG, J. (1985): A preliminary discussion of the Mid-Carboniferous boundary in China. 341-352. In Escobedo, J.L. , Granados, L.F. , Melender, B. , Pignatelli,R., Rey, R. and Wagner, R.H. (eds.), Dixieme Congr. Int. Strat. Geol. Carbon., Madrid 1983, C.R.4, Inst. Geol. Minero de Espana.

YANISHEWSKY, M. (1918): Materials of the study of the Lower Carboniferous fauna of Fergana. Mem. Com. Geol., [n. ser.], 162, 1-145, 8 pls. (in Russian). 